\title{
HTS és követő antennarendszerek alkalmazhatósága a katonai vezetést támogató múholdas távközlési rendszerekben
}

A z Új Nemzeti Kiválóság Program keretében végzett kutatásomban ${ }^{1}$ vizsgált potenciális távközlési müholdpályák közös jellemzője, hogy a műholdak a földi megfigyelőhöz (a távközlési földi állomásokhoz) képest relatív elmozdulással bírnak. Ez jelentős eltérés a jelenleg legelterjedtebben alkalmazott geostacionárius pályára helyezett múholdakhoz képest, amelyek relatív elmozdulása az alkalmazás szempontjából elhanyagolható (a műhold nem mozdul el a földi állomás antennájának iránykarakterisztikájából). Legyen szó akár az Egyenlítőhöz képest adott hajlásszöggel beállított geoszinkron pályán mozgó müholdakról ${ }^{2}$, akár szuperszinkron konstellációkról³ , a földi állomásnak követnie kell a műholdat. Ez befolyásolja az antennarendszer kialakítását. A követő antennarendszerek azonban igen jól illeszkednek a korszerű műholdas távközlési rendszerekbe, ahol a földi állomások egyre inkább nem fix telepítésüek, hanem maguk is mozognak.

Egyidejűleg a műholdak fedélzetén is érdemes a hagyományostól eltérő antennarendszereket alkalmazni. A megszokotthoz képest jelentősen nagyobb átviteli kapacitással rendelkező High-Throughput Satellite - HTS (nagy átbocsátóképességú műhold) rendszerekben megtalálható antennarendszerek kifejlesztésének célja az üzleti távközlési szolgáltatásokat nyújtó rendszerekben az volt, hogy adott rádiós sávszélességben a lehető legtöbb felhasználó részére legyenek képesek szolgáltatást nyújtani. Miközben ez természetesen a védelmi célú távközlési rendszerekben is előny, a HTS forgalomszervezésben alkalmazott antennák egyéb jellemzői miatt érdemes igazán azokat az ilyen rendszerekben alkamazni.

\section{A FÖLDI ÁLLOMÁSOK KÖVETŐ ANTENNARENDSZEREI}

A jelenlegi műholdas távközlési rendszerekben még geostacionárius pályamagasságban keringő mủholdak esetén is alkalmaznak nem irányított antennákat a földi állomáso-

ÖSSZEFOGLALÁS: Az üzleti célú műholdas távközlési rendszerekben az utóbbi években több olyan műszaki megoldás jelent meg, amelyek a védelmi és biztonsági célú - ezen belül a katonai vezetést támogató - múholdas távközlési rendszerekben is komoly hozzáadott értékkel rendelkeznek. Lehetővé teszik a mozgás közbeni folyamatos, nagy sebességú adatátvitelt, növelik a természetes és emberi eredetű rádiózavarokkal (ideértve a szándékos ártó zavarást is) szembeni védettséget és biztosítják a megszokottól eltérő műholdpályák alkalmazásának lehetőségét. A tanulmány az Új Nemzeti Kiválóság Program támogatásával készült.

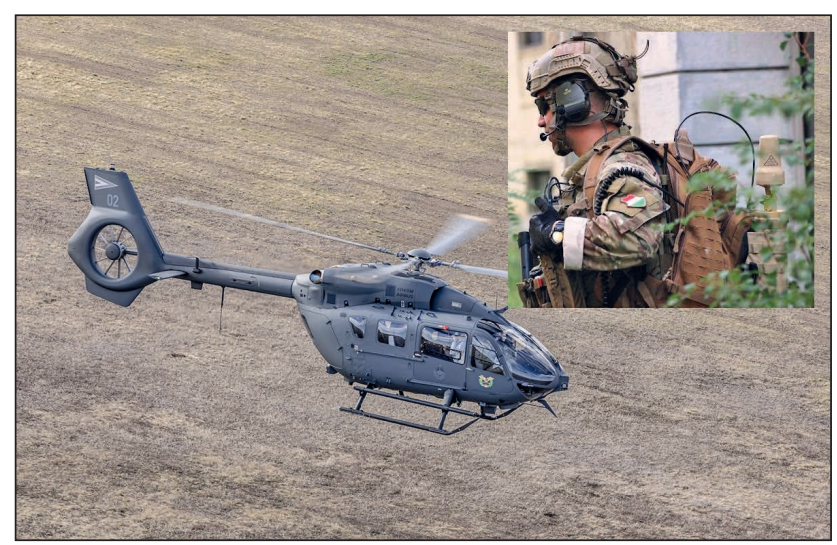

1. ábra. A Magyar Honvédség legkorszerübb müholdas rádiórendszerei. A helikopter faroktartójának jobb oldalán a vezérsík előtt látható az UHF TACSAT rendszer antennája, a jobb oldali oldalajtó felett pedig az L-TAC/SlingShot rendszer antennája. A betétképen a különleges múveleti katona felszerelésére rögzítve látható az L-TAC/SlingShot antenna (Forrás: honvedelem.hu és kulonlegesdandar.hu)

kon akkor, ha a lehető legegyszerübb kialakításra, legkisebb méretre kell törekedni. Jó példa erre a Magyar Honvédségben is használt Inmarsat L-TAC szolgáltatáshoz tartozó Spectra Slingshot antennája. Itt a kompakt kialakítás, a maximális környezetállóság és a legnagyobb működésbiztonságra való törekvés volt az optimalizáció fő szempontja. Ez rádiótechnikai szempontból azonban azt eredményezi, hogy az antenna nyeresége alacsony az első közelítésben gömbsugárzónak tekinthető kialakítás miatt. A mủholdon lévő nagy nyereségű antenna lehetővé teszi az összeköttetés létrehozását ilyen földi terminálokkal is, azonban az elérhető átviteli kapacitás igen korlátozott.

A megoldást az irányított antenna alkalmazása jelenti, mint azt a VSAT rendszerekben, illetve a nagy átviteli kapa-

ABSTRACT: Several technical solution appeared in the last few years in business SATCOM systems, which can give significant value to SATCOM supporting defence and security operations and military command and control systems. These solutions enable high speed on-the-move communication, increase the protection against natural and man-made radio interference (including deliberate jamming), and make possible the use of nonconventional orbits. This article was written with the support of the ÚNKP New National Excellence Program.

KEY WORDS: HTS, tracking antenna system, cellular radio system 


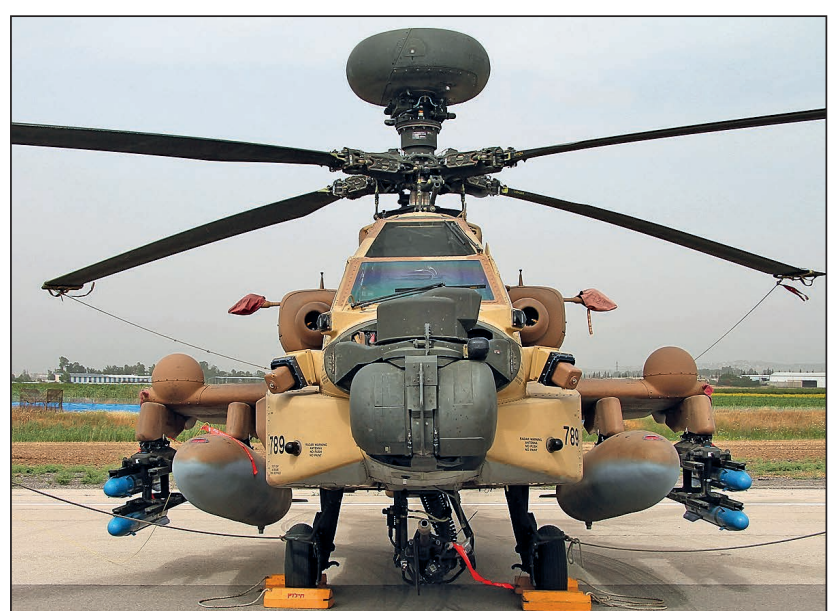

2. ábra. Az izraeli AH-64D Saraf harci helikoptert fejlett szenzorokkal szerelték fel, amelyek közül a legszembetünőbb az AN/APG-78 (Longbow) milliméteres hullámhosszú tüzvezérlő radar célgyújtő́ rendszere, valamint a radarfrekvencia interferométer. Mindkét eszköz a fö rotor feletti kupolában helyezkedik el (Forrás: jetphotos.net - ErezS)

citású forgalomdíjas műholdas adatátviteli szolgáltatási rendszerekben (mint az Inmarsat BGAN vagy GlobalXpress) láthatjuk. Ekkor a földi állomás antennája is nagy nyereségü, vagyis sokkal jobb rádiótechnikai jellemzőkkel rendelkező rendszerrel lehet dolgozni. Az elérhető adatátviteli sebességek emiatt nagyobbak az ilyen rendszerek esetében. A korszerű katonai vezetéstámogató infokommunikációs rendszerekben a kis sebességű szolgáltatásoknak is van helyük, de a nagy átviteli sebesség igénye egyre nő. A telepíthető és mobil (páncélozott harcjárművön, helikopteren vagy merevszárnyú repülőeszközön kialakított) vezetési pontok, a „digitális harcjárművek” (számítógéppel támogatott vezetési rendszerrel és számos szenzorral felszerelt modern harcjárművek, mint például a Rheinmetall Lynx, a Puma vagy a Redback) és a személyzet nélküli járművek (légi, földfelszíni vagy vízi eszközök) számára létfontosságú a nagy adatátviteli sebesség, elsődlegesen a valós idejü szenzoradat-továbbítás érdekében.

$A z$ irányított antenna még egy szempontból kiemelten fontos egy katonai távközlési rendszerben: az ellenséges elektronikai műveletek elleni viszonylagos védettség szempontjából. Mivel a kisugárzott energia (illetve szigorúan véve annak legnagyobb része) célzottan az ellenállomás irányába indul, a rádiófelderítők kisebb eséllyel képesek azt elfogni, bemérni. És mivel a reciprocitás elve alapján a vételi irányban is érvényesül az irányítottság, a rádiózavarás jelei is csak igen erősen csillapítva jutnak be a vevőbe. A korszerű elektronikai műveleti rendszerek képességeit figyelembe véve, és együtt vizsgálva ezt a digitalizált műveletvezetés elterjedésével, jól láthatjuk, hogy a vezetési rendszer kommunikációs komponensének védelme létfontosságú.

A követelmények szerencsés együttállását láthatjuk. A földi állomás hordozóplatformja egy mozgó jármű, vagy telepíthető vezetési pont esetében egy álló platform ugyan, de a szinte azonnali müholdra állás ekkor is követelmény. Ez eredendően szükségessé teszi a műhold követését még geostacionárius pályán keringő űreszköz esetében is, hiszen a platform maga mozog, legtöbbször még üzem közben is. Emellett a mủhold relatív elmozdulásából eredő követési igény egyszerűen kielégíthető, mind a megkívánt mozgáspályája, mind annak sebessége tekintetében (a hordozóplatform nagy szögsebességgel és előre nem jelezhető módon mozdul, míg a műhold elmozdulása ehhez

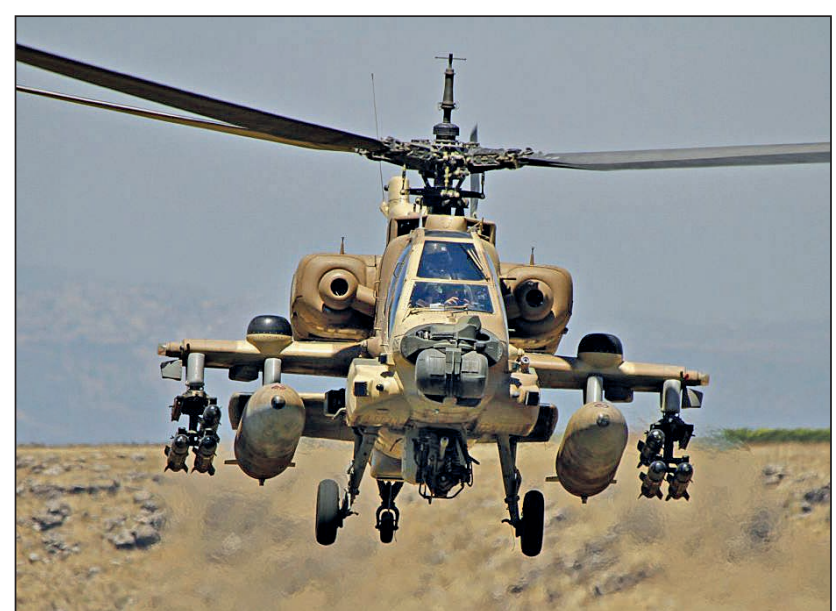

3. ábra. Izraeli AH-64A Peten harci helikopter. A félszárnyak felső részén láthatók a müholdas távközlési rendszer antennái, amelyek intenzív manőverezés közben is képesek követni a használt müholdat. A tényleges antennarendszer az áramvonalazó burkolat alatt található. (Forrás: Times of Israel)

képest lassú és jól számítható). Nem okoz hátrányt a nemgeostacionárius üreszköz megjelenése a távközlési rendszerben.

Az antenna (pontosabban az iránykarakterisztika) mozgatására több lehetőség is létezik. Rendszerben, alkalmazásban vannak még tisztán elektromechanikus mozgatású antennák, de ezek ma már nem tekinthetők korszerünek. Méretük és tömegük nagy, meghibásodási valószínűségük a sok mozgó alkatrész miatt szintén nagy. A parabolareflektor helyett réssugárzókat vagy patchsugárzókat alkalmazó megoldások fizikai mérete némileg kisebb (rosszabb antennanyereség mellett), de napjainkban ezek sem javasolhatók beszerzésre.

A manapság korszerűnek tekinthető, irányított kisugárzású követő antennák nem tartalmaznak mozgó alkatrészt a pozicionáló rendszerben. A fázisvezérelt antennarács általánosan elterjedt kialakításában a hullámhosszra méretezett elemi sugárzók sokaságából áll, amely elemi sugárzók megtápláló jelei egymáshoz képest fázisban el vannak tolva. Az eltolt fázisban kisugárzott elemi hullámfrontok sokasága a távoltérben csak egy irányban összegződik fázishelyesen, ez lesz az antennarács főnyalábja. A fázistolás megfelelő beálítása és folyamatos hangolása teszi lehetővé a főnyaláb folyamatos célon tartását. A fázistolás végrehajtható passzív fázistolók alkalmazásával (ez az alacsonyabb technológiai színvonalat igénylő megoldás), amikor az üzemi frekvenciára felkevert és erősített rádiójelet szétosztják a fázistoló hálózaton keresztül a sugárzókra. Ekkor egy erősítőnk van, az iránykarakterisztika-vezérlő a fázistolókra hat. Aktív fázisvezérlet antennarács esetén minden egyes elemi sugárzóhoz egy saját erősítő tartozik, és az iránykarakterisztika-vezérlő ezekre az erősítőkre hat. Minden elemi sugárzó közvetlenül csatlakozik a saját erősítőjéhez. Vételi irányban a működés elve azonos.

A fázisvezérelt antennarácsokat elterjedten alkalmazzák a radartechnológiában. Ezen alkalmazásban kifejezett előnyük, hogy mivel az iránykarakterisztika eltérítése nem igényel fizikai mozgatást, az antennarács fixen rögzíthető a hordozó struktúrára (köztes megoldásnak tekinthető a hazánkban is rendszeresített RAT-31DL, amely elevációban fázisvezérelt, azimutban pedig mechanikusan forgatott antennát használ). Ez nagyban csökkenti az antenna helyigényét és egyszerűsíti a mechanikai kialakítást, csökkentve ezzel a meghibásodás lehetőségét. Tovább növeli az üzembiztonságot, hogy (aktív 
rendszer esetén) a számos elemi erősítő meghibásodása egymástól függetlenül következik be, és egyes elemi erősítők kiesése ugyan rontja valamelyest az egész antennarács rádiótechnikai jellemzőit, de a rendszer egésze mégis működőképes marad („graceful degradation” - fofozatos leépülés). Ugyanezen előnyök a kommunikációs rendszerekben is érvényesülnek.

Amennyiben az antennarács elegendő számú elemből áll, és a vezérlés is képes a szükséges számítási kapacitás biztosítására, a fázisvezérelt antennarendszerek képesek több sugárnyalábot is képezni egyszerre. Az egyes nyalábok rádiótechnikai jellemzői az oda csoportosított elemi sugárzók és erősítők számától függenek. A radarok esetében ezt a „Track While Scan” üzemmód megvalósítására alkalmazzák, amikor a radar egyszerre végzi a kiválasztott cél(ok) követését (track) és a teljes légtér felderítő célú pásztázását (scan). Még egy lépéssel tovább haladva, amennyiben az egyes nyalábokba kiosztott elemi erősítőket eltérő középfrekvenciás és alapsávi rendszerbeli jellel hajtjuk meg, nemcsak az irányuk, hanem kompletten az alkalmazásuk is különböző lehet. Erre jó példát látunk az F-22-es vadászrepülőgép radarrendszerében, ahol a radar képes adatátviteli célra sugárnyalábot kikülöníteni, amelyet a vele kötelékben haladó repülőgépre irányít. $A z$ irányított kisugárzás miatt a felderítés valószínűsége igen csekély (erről kapta a nevét is: LPI - Low Probability of Intercept, magyarul: a felderítés alacsony valószínűsége). Kommunikációs rendszerben ez a képesség jól hasznosítható arra, hogy egy állomás több ellenállomással egyidejűleg tartson fenn kapcsolatot. Műholdas távközlési rendszerekben például több műhold egy antennával történő egyidejű követése történhet meg (amikor valójában már nem egy, hanem több antennáról beszélünk, amelyeket fizikailag ugyan egybe csomagoltak, de rádiótechnikailag több rendszert képeznek).

A fentebb hivatkozott szuperszinkron műholdas távközlési rendszerekben a műholdak folyamatosan felemelkednek a horizont fölé, illetve lenyugszanak. Egy terepakadályok nélküli ideális esetben, ahol a horizontra való kilátás folyamatosan biztosított, a müholdak igen alacsony elevációig követhetők, majd az elevációs maszk alá történő lenyugváshoz közeledve végrehajtható az átállás a következő műholdra. A valóságban azonban (különösen egy mozgó platform esetében, ami beépített területen vagy erdős, hegyes terepen mozog, illetve nagymértékű bólintó vagy orsózó kitéréseket hajt végre), akkor is szükség lehet műholdváltásra, amikor az éppen használt műhold még viszonylag távol van a horizonttól. Egyrészt bármikor akadály kerülhet a kisugárzás útjába, másrészt előfordulhat, hogy a platform mozgása miatt az iránykarakterisztikát olyan mélyre kellene fordítani, amire az antennarendszer, a kialakítása miatt már nem képes. Ezekben az esetekben hasznos, ha az antennarendszer a mủholdak pályaadatait ismerve folyamatosan számítja azok relatív irányát, és amennyiben egynél több mühold tartózkodik a terepakadályok nélkül elképzelt horizont fölött, akkor mindegyik irányába képez nyalábokat. Ezek közül az egyikbe allokálható a legnagyobb átviteli kapacitás, ez az üzemi nyaláb. A többi nyaláb célja kizárólag az, hogy mérve a rádiócsatorna terjedési jellemzőit, folyamatosan adatot szolgáltasson a vezérlésnek a műholdak valós láthatóságáról. Amennyiben a mérések alapján célszerü mủholdat váltani, vagy az üzemi nyaláb fenntarthatatlanná válik akadályozás miatt, az antennarendszer azonnal átkonfigurálható az aktuálisan legjobb müholdra.

A fázisvezérelt antennarácsok hátránya azonban, hogy minden egyes elemi sugárzónak a hullámhosszra méretezettnek kell lennie az optimális teljesítmény érdekében.
Alacsonyabb frekvenciákon ez a rács méretének jelentős növekedését eredményezi. Az elemi sugárzók méretének csökkentése rontja a rádiótechnikai jellemzőket. Emellett, az aktív fázisvezérelt rendszerek igen drágák.

A hullámhosszhoz képest kis méretű antennák hátrányait küszöbölik ki a metaanyagokat tartalmazó antennarendszerek. A metaanyagok által megváltoztatott elektromágneses jellemzők teszik lehetővé, hogy a kis méretű antennaelemek sokkal hatékonyabban müködjenek, mint ahogyan azt a fizikai méretük lehetővé tenné. A metaanyagok arra is használhatók, hogy hatékonyabbá tegyék a korábban leírt fázisvezérelt antennarácsok működését (csökkentik az oldalszirmokat és a veszteségeket). Jó példát találhatunk erre Carsten Metz US 6,958,729 B1 számú szabadalmában. A metaanyagok azonban más módon is hasznosíthatók az antennák kivitelezésében. Ezek egy része már kereskedelmi forgalomban elérhető (például a Kymeta termékei), mások a fejlesztés, illetve a kutatás fázisában járnak.

Figyelemmel arra, hogy akár döntött pályasíkú geoszinkron műhold, akár szuperszinkron müholdas konstelláció kerül alkalmazásra, az alkalmazott földi állomás antennarendszere nem különbözik (hiszen a műveleti alkalmazhatóság okán nem különbözhet) a jelenleg geostacionárius müholdas rendszerekben alkalmazott követő antennáktól. A földi állomás antennarendszerek ennél részletesebb tárgyalása nem szükséges.

\section{A MÜHOLD ANTENNARENDSZERÉNEK KIALAKÍTÁSA}

A geostacionárius pályán keringő műholdak antennája a legegyszerübb esetben egy hozzávetőlegesen $19^{\circ}$-os nyílásszögű sugárnyalábot kibocsátó tölcsérsugárzó, amely besugározza a teljes látható földfelszínt. Spektrumgazdálkodási és teljesítmény-optimalizációs okok miatt a legtöbb távközlési műhold azonban nem sugározza be a teljes látható földfelszínt, csak annak egy részét. Ehhez klasszikusan a kívánt lefedettségi területformának megfelelő elrendezésü sugárzóhálózatot alakítanak ki, amelynek képét (kisugárzási karakterisztikáját) parabolareflektor vetíti le a felszínre. A sugárzóhálózatot vagy egy erősítő hajtja meg - vagyis az összes elemi sugárzó egy rádiófrekvenciás rendszer része -, vagy pedig külön-külön erősítőhöz és RF rendszerhez kapcsolódnak. Ekkor a kivetített lefedettségi terület szegmentálható.

A szilárdtest-teljesítményelektronika fejlődése azonban ebben az esetben is lehetővé tette, hogy az elemi sugárzókhoz elemi erősítőket csatlakoztassanak, vagyis minden sugárzó (a hozzá tartozó erősítőn keresztül) önálló rádiófrekvenciás rendszer antennájaként szerepeljen. Az erősítők és a mögöttük található rendszerek aktív kapcsolásával pedig elérhető, hogy az elemi sugárzók igény szerint öszszekapcsolhatók legyenek. Mivel minden elemi sugárzó képe kivetítődik a földfelszínre, így összességében nem egy lefedettségi területet kapunk a teljes antennarendszerre értelmezve, hanem minden elemi sugárzó egy saját, jelentősen kisebb méretű lefedettségi területet képez. Az angol szakirodalomban használt spotbeam kifejezés tükörfordításaként, ezeket pontnyaláboknak nevezzük.

Mivel minden pontnyalábot külön erősítő táplál, ami mögött külön jelfeldolgozó rendszer található, a szomszédos pontnyalábok eltérő frekvencián üzemelhetnek. A térben egymástól távol eső pontnyalábok használhatják ugyanazt a frekvenciatartományt egymás zavarása nélkül. Ezzel a módszerrel gyakorlatilag egy cellás rádiórendszert alakítanak ki a műholdon, azonban a cellákat nem a bennük talál- 


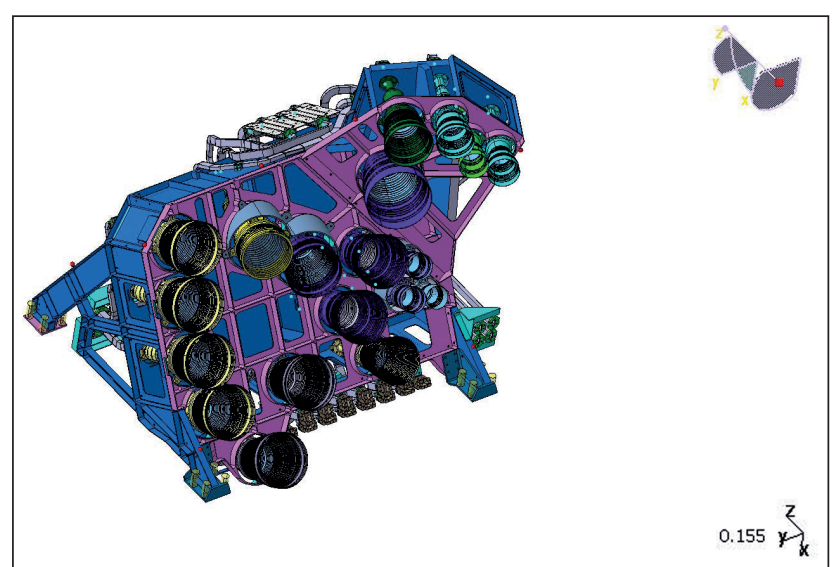

4. ábra. Az ESA ARTES programjában az Astrium/Airbus által fejlesztett LMFA sugárzórendszer (Forrás: ESA)

ható bázisállomások képezik, hanem a műhold antennarendszerének elemei sugárzói (és a cellaelrendezést esetenként még egy reflektor vetíti le a felszínre).

A cellás rádiórendszerek leginkább ismert előnye a frekvenciák újrahasznosíthatósága. Mivel a rádiófrekvenciás spektrum véges erőforrás, optimális kihasználása minden rendszertervező alapvető feladata. A földi cellás rendszerekben az egyik cellában használt spektrumtartomány kiosztható egy másik, távolabb lévő cellában újból, amennyiben a rádiós terjedési viszonyok (légköri csillapítás, domborzat) megfelelő elválasztást biztosít. A műholdról képzett cellák esetében az újra kioszthatóság az antenna térbeli szűrőként történő működéséből adódik: a pontnyaláb lefedettségi területén kívülről érkező rádiójelek be sem jutnak a vevőbe, mert a reflektor nem vetíti az elemi sugárzóra azokat.

A frekvencia-újrahasznosítás magyarázataként képzeljünk el egy rádiórendszert, ami a teljes megkívánt szolgáltatási területet egyben fedi le (nincs cellákra vagy pontnyalábokra osztva). Az egyszerüség kedvéért most csak egyirányú szimplex kommunikációt vizsgálunk, de kétirányú kommunikáció esetén is azonos az elv. A rendszerben használjunk $400 \mathrm{MHz}$ rádiós sávszélességet, 4 darab, egyenként $100 \mathrm{MHz}$ sávszélességű csatornára bontva (például 1000-1099, 1100-1199, 1200-1299, 1300-1399 MHz). Mivel fizikailag nincs felszabdalva a szolgáltatási terület, bárhol is helyezkedjenek el a felhasználói állomások, amennyiben egy csatornát egy felhasználó foglal, az a teljes szolgáltatási területen foglaltnak tekintendő, így a rendszerben a felhasználók számára elérhető sávszélesség megegyezik a rádiós sávszélességgel.

Osszuk fel most a szolgáltatási területet $3 \times 3$ cellára $(A$, B, C; 1, 2, 3). Kössük ki, hogy a szomszédos cellában nem lehet újra használni a csatornát, egy elválasztó cellának lennie kell az azonos csatornát használó cellák között. Ebben az esetben a vivők használhatósága így alakul:

1000-1099: A1, A3, C1, C3 (400 MHz);

1100-1199: A2, C2 (200 MHz);

1200-1299: B1, B3 (200 MHz);

1300-1399: B2 (100 MHz).

Láthatjuk, hogy a $400 \mathrm{MHz}$ rádiós sávszélességben $900 \mathrm{MHz}-n y i$ átviteli kapacitás áll a felhasználók rendelkezésére abban az esetben, ha a forgalom nem lépi át a cellahatárt. Határátlépés esetén a cellákat, pontnyalábokat össze kell kapcsolni (ennek felismerése a forgalomkezelő rendszer feladata), és ekkor a sávszélességigény megnő, hiszen mindkét cellában foglal kapacitást a forgalmazás. Amennyiben például az A2-t a C2-vel kell összekötni, akkor az oda tervezett $100 \mathrm{MHz}$ kapacitást csak egyszer lehet

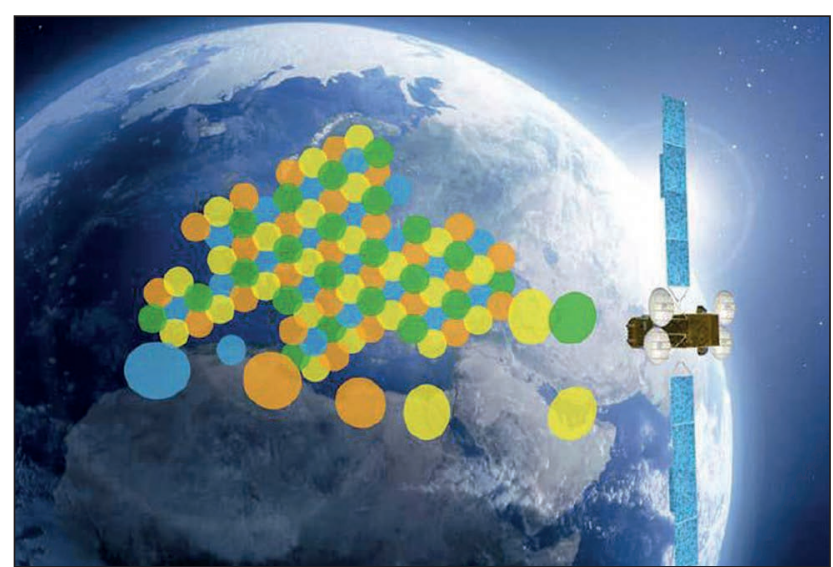

5. ábra. HTS rendszer cellakiosztása a gyakorlatban (Forrás: EUTELSAT)

kiosztani, nem pedig kétszer. Természetesen a valós cellás rendszerekben sokkal nagyobb cellaszámmal és bonyolultabb vivőkiosztással kell számolni, de az elvek bemutatásához ez a példa elegendő.

Az ilyen cellás szervezésű távközlési műholdakat HighTroughput Satellite-nek (HTS) (nagyon nagy átbocsátóképességű műhold) nevezzük. A név magyarázata, hogy a cellás forgalomszervezésnek és a nagy teljesítményű erősítőknek köszönhetően ezek a müholdak szignifikánsan nagyobb átviteli kapacitással rendelkeznek, mint a korábbi űreszközök. Azonban - ahogy azt az előző példából is láthattuk -, ez a kapacitásnövekmény esetenként csak látszólagos, mert nagyban függ a forgalom áramlási irányától, a felhasználói állomások elhelyezkedésétől.

A védelmi célú műholdas távközlési rendszerekben a pontnyalábos HTS forgalomszervezés más szempontból bír nagy jelentőséggel. A fentebb említett térbeli elhatárolás eredményeként az adott pontnyalábba kisugárzott rádiójelek nem vehetők a pontnyaláb területén kívülről, és nem lehetséges a pontnyaláb területén kívülről zavarjeleket besugározni a nyalábba. Ismételten azt láthatjuk, hogy az ellenséges rádióelektronikai műveletek elleni védettséget sokszorosára növeli a szolgáltatási terület cellákra osztása.

A HTS műholdak lehetőséget biztosítanak a cellák átrendezésére is, mert a sugárzórendszer fázisvezérelt. Az egyes cellák mérete kiterjeszthető vagy összezsugorítható, és helyük is változtatható az elméletileg belátott területen belül. Ez egyrészt alapvető szükségszerűség abban az esetben, ha a műholdnak relatív elmozdulása van a földfelszíni megfigyelöhöz képest, mert a földfelszínre vetített képnek (a cellakiosztásnak) állandónak kell lennie. Szuperszinkron elliptikus pályán keringő műholdak esetében még inkább fontos a cellakép folyamatos hangolása, mert ott nagymértékben változik a földfelszínre való rálátás.

A cellák átrendezésének lehetősége teszi alkalmassá a HTS műholdarchitektúrát arra, hogy mindig az aktuális műveleti feladathoz alkalmazkodva képezze a lefedettségi területet. Az űreszközök jellemzője, hogy a műszaki képességeiket a pályára állítás előtt kell meghatározni és kialakítani, utána azon változtatni távkonfigurációval csak akkor lehet, ha ez a változtatási képesség rendelkezésre áll. Egy hagyományos, sugárzóhálózattal formált nyalábot alkalmazó műhold esetében a szolgáltatási terület fix. Amennyiben ez a szolgáltatási terület átnyúlik az ellenség által ellenőrzött földrajzi területre, akkor a mühold teljes mértékben kitett a zavarás és a forgalom-lehallgatás veszélyének. A HTS architektúrával időben és térben is lehet változtatni a lefedett területet, vagyis az ellenség területére csak 


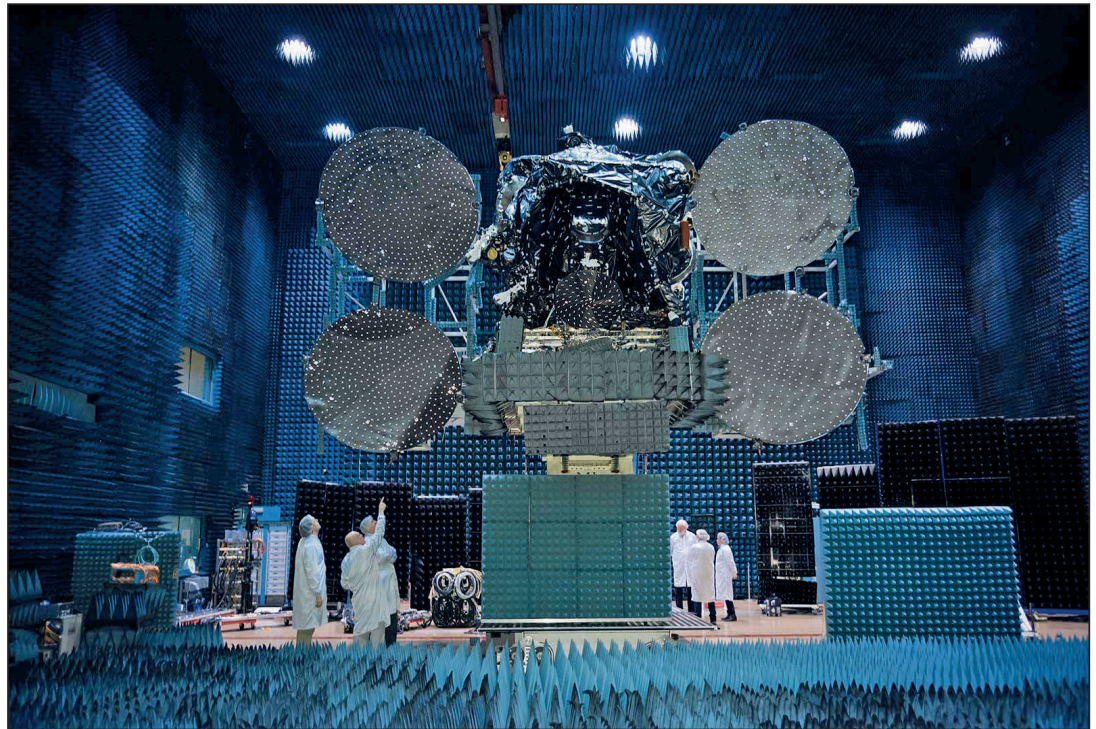

6. ábra. Az Azerspace-2 többfeladatú távközlési mühold antennarendszere (Forrás: MAXAR)

akkor, és csak oda lehet pontnyalábot képezni, amikor és ahová szükséges. Figyelembe kell venni azonban azt, hogy egy ilyen nyalábképzés könnyen észlelhető - ami egyben arra is lehetőséget ad, hogy az információs müveleti tervben a megtévesztés eszközeként szolgáljon.

A kutatási programban eddig vizsgált geoszinkron és szuperszinkron műholdpályákra helyezett müholdak közül az első esetben nem szükséges a műholdfedélzeti HTS antenna- és sugárzórendszer módosítása, azonban a szuperszinkron esetben igen. Az elliptikus pályák miatt a műholdak távolsága jelentősen nagyobb a geoszinkron (geostacionárius) távközlési műholdak esetében megszokottnál, és ráadásul folyamatosan változik is.

A változó távolság miatt módosul a megvilágítandó terület relatív mérete, így változtatni szükséges a nyalábdivergenciát. Kiindulva abból, hogy a végleges antennarendszer továbbra is egy fázisrács sugárzó hálózattal megvilágított reflektorként alakítható ki a legcélszerübben, a nyalábdivergencia (vagyis az antenna fókusztávolsága) úgy módosítható, hogy a megvilágító sugárzórendszert nemcsak két, hanem három dimenzióban vezérelve üzemeltetjük. A sugárzók meghajtásánál így nemcsak fázisban, hanem időtartományban is el kell tolni a vezérlőjelet a szükséges mértékben. Ezáltal a sugárzó egyben egy virtuális segédlencseként is működik. Mivel a cél az, hogy az aktuális rádiótervnek (szolgáltatási tervnek) megfelelő lefedettségi mintát vetítse ki az antennarendszer a földfelszínre, az antennavezérlő működésének logikai útja az, hogy először is a földfelszín beláthatóságának megfelelően kialakítja a kivetítendő lefedettségi mintát (előtorzítva úgy, hogy annak a gömbfelületnek tekinthető földfelszínre való vetülése a megfelelő szolgáltatási területet alkossa), majd ezt a mintát defókuszálja úgy, hogy az állandó fókusztávolságú reflektorról visszaverődve a minta pontosan az aktuális távolságban lévő földfelszínen legyen fókuszban. Ahogyan a mű- hold bejárja pályáját (a felhasználói igényeket állandónak tekintve) folyamatosan változtatni kell a földfelszínre való rálátás irányának megfelelően a síkbeli előtorzítást, a távolság változásának megfelelően pedig a defókuszálást.

$\mathrm{Az}$ antennareflektor mérete meghatározza a müholdfedélzeti rendszer eredő antennanyereségét. Nagy nyereségű antenna alkalmazásával megkönnyíthetjük a földi állomások antennájának kivitelezését. Ugyan a műholdon nem könnyű nagy méretű antennát elhelyezni, de ebből csak korlátozott darabszámra van szükség (a bemutatott szuperszinkron konstellációk közül a legnagyobb is csak 8 múholdat használ), míg a földi állomások száma sokkal nagyobb. Ismételten vegyük figyelembe, hogy a potenciális felhasználók a katonai műveletvezetési rendszer elemei, amelyek a korszerű harc követelményeinek megfelelően mozgó járműveken, repülőeszközökön vagy a katona egyéni felszerelésében helyeznek el, így méretük jelentősen korlátozott lehet bizonyos esetekben.

A polgári távközlési műholdakon is megtalálhatunk ma akár 12 méter átmérőjű antennareflektort. Ez természetesen a pályára állítás során összecsukott állapotban van, és csak az üzemi röppálya elérését követően nyitódik ki. Ezzel az antennával az Inmarsat-4 és Thuraya műholdak a geoszinkron pályamagasságból képesek szolgáltatást nyújtani mobiltelefon méretű, nem irányított antennával felszerelt földi állomások számára

Nem ezek voltak azonban a legnagyobb antennák geoszinkron műholdakon. A Rhyolite / Aquacade fedőnevű kémmüholdsorozat feladata mikrohullámú adatátviteli rendszerek, illetve ballisztikusrakéta-tesztek során alkalmazott telemetriai rendszerek lehallgatása volt. Ehhez hozzávetőlegesen 20 méter átmérőjü parabolareflektorral kialakított antennarendszert használt. Ezeket a műholdakat az 1980-as évek elejéig tartották rendszerben. Utódjuk, a Magnum / Mentor / Orion sorozat antennarendszere, a

7. ábra. 14 sorozatú mühold kinyitott antennareflektorral (Grafika - Forrás: ESA)

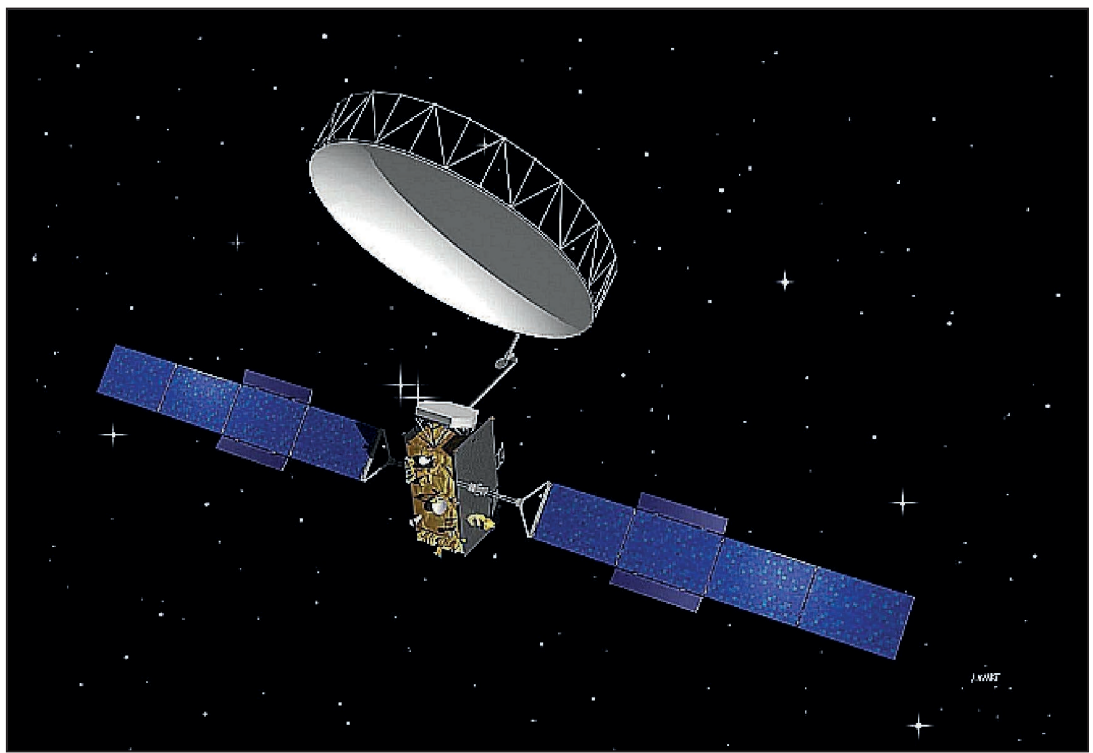




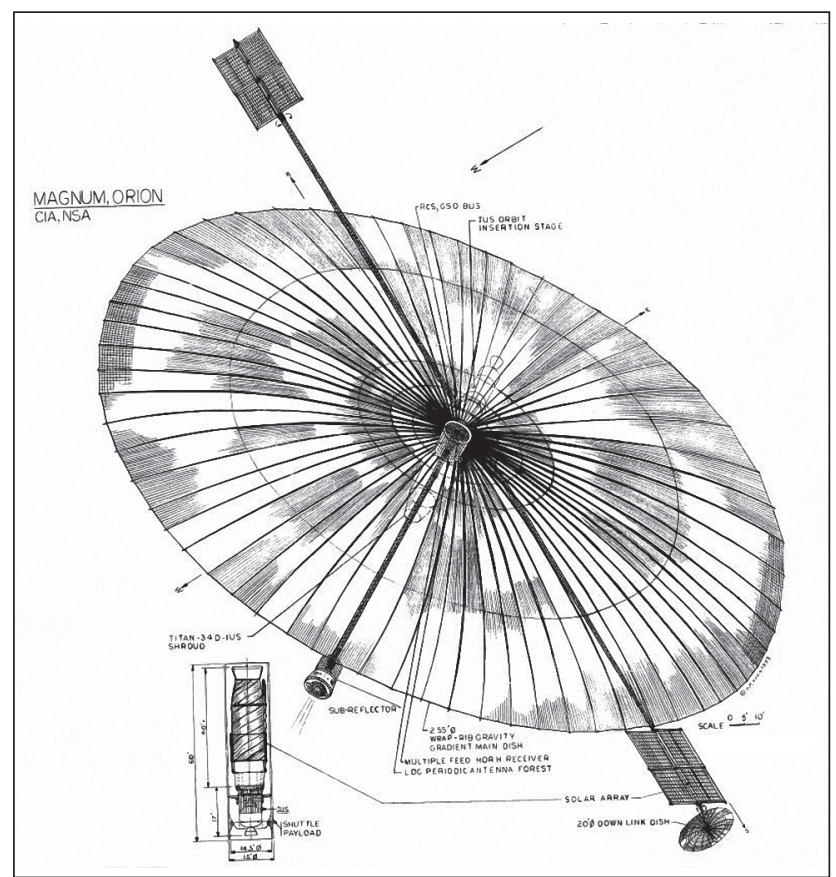

8. ábra. Magnum/Orion elektronikai felderítő mühold nyitott antennarendszerrel (Forrás: globalsecurity.org)

nyilvánosan elérhető források szerint 80-100 méter átmérőjű reflektort tartalmaz.

Látható tehát, hogy a technikai feltételek adottak a megfelelő műholdfedélzeti antennarendszer kialakításához. A HTS forgalomszervezés megteremti a védett és nagy átviteli kapacitású távközlési rendszer irányítását, a három dimenzióban kontrollált megvilágító sugárzó lehetővé teszi az elliptikus pályák alkalmazását, a nagyméretű antennareflektor pedig a nagy távolságból történő kommunikációt biztosítja a rosszabb rádiótechnikai jellemzőkkel rendelkező földi állomások számára is.

Az antennarendszer lehetőségeinek vizsgálatával a hivatkozott kutatási programom lezárul. Ez azonban nem jelenti azt, hogy a feladatot maradéktalanul elvégeztük volna. Hátra van még egy nagyon komoly megoldandó probléma, mégpedig a forgalomkezelő rendszer, a kommunikációs protokollok vizsgálata. Az elliptikus pályákon mozgó műholdak távolsága változik, ezt már említettük az antennarendszerrel kapcsolatban is. De emiatt változik a futási idő is, sőt, a szuperszinkron pályamagasság miatt ez a futási idő eleve hosszabb, mint a geoszinkron pályamagasságban. Ismert a müholdas távközlési gyakorlatban, hogy a földi üzemre tervezett informatikai hálózatvezérlési protokollok - elsődlegesen a TCP -, nem müködnek optimálisan geoszinkron műholdas kapcsolaton, kiegészítő technikai megoldásokra van szükség a teljesítményvesztés megelőzése érdekében. A szuperszinkron műholdaknál ez még fokozottabban jelentkezik, és komoly odafigyelést igényel majd - biztosra vehetjük, hogy teljesen új kommunikációs protokollok kifejlesztésére lesz szükség.

\section{Összegzés}

Az a mód, ahogyan a világűrt napjainkban hasznosítjuk, fenntarthatatlan. Sem az alacsony Föld körüli pályán, sem a geostacionárius övben nem folytatódhat úgy az űrtevékenység, ahogyan ma zajlik. Jelen tanulmány írásakor éppen égimechanikai és adatelemző szakemberek tucatjai számolták, vajon összeütközik-e két, összesen több mint két és fél tonna tömegü, üzemen kívüli műhold épp abban a magasságban, ahová az egykori szovjet óceánfelderítő műholdak (US-A sorozat) atomreaktorait parkolópályára helyezték. 2020 január-februárjában a szakma aggódva figyelte, vajon sikerül-e kimanőverezni a Spaceway-1 müsorszóró műholdat a geostacionárius pályáról még azelőtt, hogy az akkumulátorai felrobbannának. Történt már ilyen robbanás korábban (DMSP-F13 az alacsony Föld körüli pályán), azóta tudjuk, hogy egy ehhez hasonló esemény következményei katasztrofálisak. Alig nyugodhattunk meg, máris érkezett márciusban a hír, hogy a VeneSat-1 „Simón Bolívar" távközlési műhold irányíthatatlanná vált, és az operátorok vészeljárással igyekeznek eltávolítani a többi üzemelő műhold pályatartományából. Ez a pályamódosítás csak részben sikerült mielőtt a mühold teljesen irányíthatatlanná vált, ezért most naponta „visszalátogat” az aktív térrészbe. Láthatjuk, hogy 2020 az űrben is a vészhelyzetek éve volt, és ki kell mondanunk, hogy a katasztrófákat nem elkerülni, hanem megúszni sikerült.

A trendek nem arra utalnak, hogy kedvező irányba mozdulna el az űrtevékenységek végrehajtása. Emiatt kell felkészülnünk arra, hogy ezt a két, egyszerüen és gazdaságosan hasznosítható világűrbeli térrészt néhány év, legfeljebb évtized alatt elveszítjük. Könnyen lehet, hogy a ma pályára álló geostacionárius müholdak lesznek az utolsók, amelyek még hasznos élettartamukat ki tudják tölteni itt.

A kutatási programban vizsgált pályák alkalmasak arra, hogy új alapokra helyezzük a világür hasznosítását, új térrészeket nyissunk meg, vagy jelenleg is használt térrészt új szempontok alapján hasznosítsunk. Ez növeli az űrrendszerek védettségét a természetes és emberi eredetü veszélyforrásoktól, beleértve a rosszindulatú emberi károkozási szándékot (műholdelhárító fegyverek alkalmazását) is.

A kutatási program hivatkozott korábbi publikációi bemutatták a vizsgált pályák égimechanikai jellemzőit és alkalmazhatóságukat. Jelen tanulmány pedig kifejezetten a földi állomások és a müholdak antennarendszere, illetve a frekvenciamenedzsment szempontjából vizsgálta, hogy a ma is meglévő, technológiailag kidolgozott rendszerszervezési elvek és módszerek, az eredeti fejlesztési céljuktól eltérően milyen előnyöket nyújtanak a védelmi és biztonsági célú űrtávközlési rendszerekben.

Megállapíthatjuk, hogy ezek a műszaki megoldások nem pusztán kényszerből alkalmazandók az új műholdpályák hasznosításához, hanem az irányított kisugárzás és a szolgáltatási terület rugalmas felosztása révén komoly védelmet képesek nyújtani a rádióelektronikai múveletek hatásaival szemben is. Így alkalmazásuk elengedhetetlenül szükséges a korszerű műveletvezetési rendszerekben.

\section{Köszönetnyilvánítás:}

A publikáció elkészítését az Innovációs és Technológiai Minisztérium Új Nemzeti Kiválóság Program támogatta, a Nemzeti Kutatási, Fejlesztési és Innovációs Hivatal szakmai együttműködésével. ÚNKP azonosító: ÚNKP-19-3-INKE-22. http://unkp.gov.hu

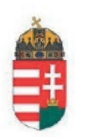

NEMZETI KUTATÁSI,

FEJLESZTÉSI ÉS INNOVÁCIÓS HIVATAL

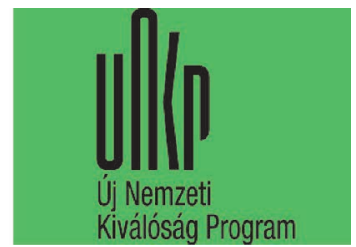


FELHASZNÁLT IRODALOM

[1] Carsten Metz. Phased Array metamaterial Antenna System, United States Patent nr. US 6,958,729 B1, 2004 március 8. Elérés: 2020. 11. 10. https:// patentimages.storage.googleapis.com/c5/a7/ d2/152115c3e7683d/US6958729.pdf;

[2] Aycan Erentok, Richard W. Ziolkowski. MetamaterialInspired Efficient Electrically Small Antennas, 2008 március. Elérés: 2020. 11. 10. https://uweb.engr. arizona.edu/ ziolkows/research/papers/Metamaterial_ Research/Antennas/Erentok_Ziolkowski_IEEE_Trans_ AP_Mar_2008.pdf;

[3] Exhibit D Inmarsat 4F1 \& 4F3 Technical Description, Elérés: 2020. 11. 10. licensing.fcc.gov/myibfs/ download.do?attachment_key=143731\&usg=AOvVaw0wjK60Gf_Jhum4nGOvTyUC;

[4] Boeing Commercial Satellite Services Inmarsa-5: Overview Brief for Arctic, 2014 augusztus, https://www. ntia.doc.gov/files/ntia/boeing_satcom_for_alaska1.pdf , letöltve: 2020.07.06.;

[5] Charles P. Vick. MAGNUM-ORION NRO/CIA/NSA SIGINT Spacecraft, 2007 Elérés: 2020. 11. 10. https:// www.globalsecurity.org/space/systems/magnum.htm;

[6] Orion 1,2 (Magnum 1,2) Elérés: 2020. 11. 10. https://space.skyrocket.de/doc_sdat/orion-1_nro.htm.

\section{JEGYZETEK}

1 ÚNKP azonosító: ÚNKP-19-3-I-NKE-22.

2 Az előadáshoz kapcsolódó szimulációk megtekinthetők a https://horvath.space/comconf-2019-material/ címen.

3 A tanulmány a Haditechnika folyóirat 2020/6. szám 35-42. oldalán jelent meg (DOI:10.23713/HT.54.6.08);

a kapcsolódó szimulációk megtekinthetők

a https://horvath.space/draim-hemispheric/

és https://horvath.space/modified-draim-tetrahedral/ címeken.

\section{Törös István}

\section{A csillagok útján}

\section{Farkas Bertalan, az első magyar ürhajós}

Biztosan sokan gondoltak már arra, hogy naponta hányszor tekintünk fel az égre, kémlelve az időjárást, figyelve a felhőket, este meg a holdat és a csillagokat. Farkas Bertalannak megadatott, ami csak nagyon keveseknek, ő a világürből is szemlélhette csodálatos világunkat.

1980. május 26-án, magyar idő szerint 20 óra 20 perckor, az Interkozmosz program keretében indult el Bajkonurból a világűrbe az első magyar űrhajós, Farkas Bertalan fedélzeti mérnök Valerij Kubaszov parancsnokkal a Szojuz-36 űrhajó fedélzetén. Magyarország a hetedik „űrnemzet” a világon, amelynek állampolgára eljutott a Föld körüli pályára. A számos, korábban még nem publikált fotóval illusztrált kiadvány a gyulaházai szülői házból indulva meséli el az

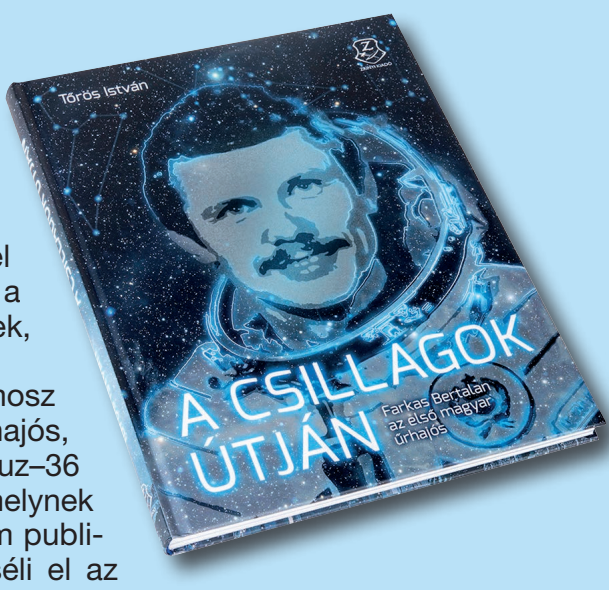
akkor még Bertinek hívott szorgalmas tanuló, jól sportoló fiatalember életútját.

Gimnázium, szolnoki Repülőműszaki Főiskola, Szovjet Repülőműszaki Főiskola, majd következett Pápa, ahol a magyar légierő tisztje 1976-tól első osztályú vadászrepülő lett. De mitől vadászpilóta a vadászpilóta? Látszólag csak három dolog szükséges a mesterséghez: bőrdzseki, napszemüveg és speciális pilótaóra. Ez a felszerelés már a '60-as években is megvolt a kiválasztottaknak. Ahhoz azonban, hogy valaki az ég katonája legyen, sokkal több elvárásnak kell megfelelnie. Az első osztályú vadászpilóta számára előírt követelmény a bármely napszakban és időjárási viszonyok közötti hadrafoghatóság. Minden körülmények között tökéletesen kell repülnie, az ehhez vezető tudás hosszú, egymásra épülő tanulási folyamatok nyomán szerezhető meg. Farkas Bertalan százados 1978-ban kezdte meg az űrhajós kiképzést. 1980-ban, a Szojuz-36 űrhajó fedélzetén az alábbi rádióüzenettel várta a kilövés pillanatát: „Jelentem: a Szojuz-36 űrhajó fedélzetén űrrepülésre kész vagyok. Minden tudásomat, erőmet megtisztelő feladatom maradéktalan végrehajtásának szentelem". Az asztronauta 7 nap 20 óra 45 perc után befejezte küldetését.

Az egykori százados - ma már nyugalmazott dandártábornok - az Ürhajósok Nemzetközi Szövetsége és a Space for Earth Alapítvány alapító tagja, az MTA Interkozmosz Tanács kutatócsoportjának munkatársa. Az űrutazás során leghíresebb kísérleti programja az Interferon volt, de a Dóza-kísérletben részt vevő, a KFKI által gyártott Pille sugárdózismérő is rendkívül jelentős eredményt hozott a későbbi kutatások számára az országnak. Farkas Bertalan, tevékenységével nemzetközi elismerést vívott ki Magyarországnak, és mind a mai napig részt vesz az űrkutatás népszerűsítésében. A kötet érdekfeszítő olvasmány azoknak, akik tisztelik és megbecsülik az emberi teljesítményt, kitartást, érdeklődnek napjaink legsokoldalúbb tudományos és technikai kutatásai, a világűrhöz kapcsolódó tevékenységek iránt. A magyar ürutazás 40. évfordulója alkalmából megjelent, Tőrös István által szerkesztett kötet sokoldalúan, személyes stílusban mutatja be a vadászpilóta, űrkutató pályáját napjainkig.

A Zrínyi Kiadó által 2020-ban megjelentetett cérnafüzött, keménytáblás, számos fotóval illusztrált kötet terjedelme 169 oldal. 7800 Ft-os áron kaptaható a könyvesboltokban, illetve közvetlenül a Zrínyi Kiadótól is, 25\%-os helyszíni kedvezménnyel. Cím: 1024 Budapest, Fillér utca 14., (tel.: 06 1-459-5373, e-mail: cinti@hmzrinyi.hu-ra), továbbá megrendelhető a shop.hmzrinyi.hu weboldalon. (F.K.F.) 